\title{
COMPARISON OF HIGHLY SENSITIVE CRP AND SERUM CREATININE AS AN EARLY MARKER OF RENAL IMPAIRMENT
}

\author{
ROKSANA YEASMIN ${ }^{1}$, MD. NIZAMUL HOQUE BHUIYAN ${ }^{2}$, SULTANA PARVEEN ${ }^{1}$ \\ SHAMIM ARA FERDOUS ${ }^{3}$, NAZMUN NAHAR ${ }^{1}$
}

\begin{abstract}
:
A case control study was done during the period of July 2004 to 2005. The study was carried out in the Department of Biochemistry, Dhaka Medical College, Dhaka. 50 diagnosed chronic renal failure patients of both sexes not yet treated by dialysis and 50 age and sex matched healthy subjects were included in the study as case (Group-II) and control (Group-I) respectively. In this study, mean serum HS CRP concentration of CRF patients $(50.938 \pm 38.88) \mathrm{mg} / \mathrm{l}$ found to be significantly elevated in comparison to control $(1.12 \pm .29 \mathrm{mg} / \mathrm{l})$. In CRF patients, serum HS CRP found to show a strong negative correlation with creatinine clearance and a strong positive correlation with blood urea, serum creatinine. This study shows an inverse linear relationship between HS CRP and CCRin contrast to the inverse curvilinear relationship found to exist between serum creatinine and creatinine clearance. Regression analysis between CCR and HS CRP shows a rise of HS CRP Y one unit $(\mathrm{mg} / \mathrm{l})$ is accompanied by creatinine clearance to be decreased by $0.44 \mathrm{ml} / \mathrm{min}$. Mean serum HS CRP concentration in chronic renal failure increases significantly. Early phase of decreased CCR can not be detected by the serum creatinine because serum creatinine does not increase until there is significant fall ( $30 \mathrm{ml} / \mathrm{min}$ ) of creatinine clearance. In contrast to this serum HS CRP begins to rise from the very beginning of the fall of creatinine clearance. So the early phase of decreased creatinine clearance could be detected by simultaneous rise of serum HS CRP.
\end{abstract}

Key Words: HS CRP, CRF, CCR.

\section{Introduction:}

Chronic renal failure is a big public health problem all over the world. Renal failure is common in developing countries, particularly in tropical areas like Bangladesh ${ }^{1}$. Chronic renal failure is an irreversible deterioration in renal function, which classically develops over a period of years. Initially, it manifests only as a biochemical abnormality. Eventually, loss of the excretory, metabolic and endocrine functions of the kidney lead to the development of the clinical symptoms and signs of renal failure. CRF may be caused by any condition, which destroys the normal structure and function of the kidney. The most common causes of CRF are glomerulonephritis, diabetes mellitus, hypertension, renal artery stenosis and polycystic kidney disease ${ }^{2}$.

On the basis of creatinine clearance chronic renal failure can be divided in to 3 groups. These are mild $(60-70 \mathrm{ml} / \mathrm{min})$, moderate $(30-60 \mathrm{ml} / \mathrm{min})$ and severe
$(15-30 \mathrm{ml} / \mathrm{min})^{3}$. Serum Creatinine screening has been used as a tool to identify individuals who are at increased risk of developing future kidney disease or impaired renal function. It is well known to everyone that high serum Creatinine and low Creatinine clearance contribute to renal function loss 4 . Although, this approach has been useful, it fails to identify almost half of the individuals with mildly increased serum Creatinine who develop chronic renal failure each year. So, other laboratory tests, although less well known, can also help to predict renovascular diseases. These additional assays are related to chronic inflammation ${ }^{4,5}$.

HS CRP is the acute phase protein, which is produced by liver. It has been used for many years as a very sensitive marker of systemic inflammation. Normally its circulatory level is low but infection, inflammation or tissue injury induces a marked increase in hepatic synthesis of HS CRP and may exceed $300 \mathrm{mg} / \mathrm{l}$ with in 48 hours of an acute event.

1. Department of Biochemistry, Ibrahim Medical College

2 Institute of Food \& Nutrition, Dhaka University

3. Infectious Disease Hospital 
High levels may persist in chronic inflammatory status $^{5}$. HS CRP production is mediated by several inflammatory mediators like interlewkin-6 (IL-6). CRP and IL- 6 both are elevated in chronic renal failure patients ${ }^{6}$. Stuveling et al., in 2003 had done a prospective study regarding the association of HS CRP with renal function abnormalities in a large non diabetic population. They found positive correlation between renal function loss \& elevated C-reactive protein level. They found an inverse relationship in between $\mathrm{HS}$ CRP and creatinine clearance ${ }^{7}$.

\section{Patients and Methods}

This case control study of serum HS CRP and blood urea, serum creatinine and creatinine clearance in CRF patients was carried out in the Department of Biochemistry, Dhaka Medical College, Dhaka during the period of July 2004 to July 2005. 50 diagnosed chronic renal failure patients of both sexes yet not treated by dialysis and 50 age and sex matched healthy subjects were included in the study as case (Group-1I) and control (Group-I) respectively. Patients having age more than 45 years, smoker, alcoholics, severe skeletal muscle disease, history of trauma, diabetics, and hypertensive were excluded from the study. After having deliberate conscent from patient, data was collected and $5 \mathrm{ml}$ venous blood was drawn aseptically. Then the blood immediately transferred to a dry clean test tube and allowed to clot. The sample was then centrifuged and serum was collected in an ependrop tube appropriately and then labeled and preserved at $-20^{\circ} \mathrm{C}$ in a refrigerator before estimation. Random blood glucose was first estimated with the sample to exclude the diabetic subjects. HS CRP, urea, creatinine and creatinine clearance were then estimated in the preserved sample. HS CRP measured by immunonephelometric method, and blood urea, serum creatinine measured by enzymatic colorimetric method and creatinine clearance by Cockcorf formula to find out the significance. Data were analyzed by using SPSS software. Mean values of the different parameter were compared by 'Mann Whiteny U' test and ' $r$ ' test to see the level of significance. $95 \%$ confidence limit $(\mathrm{p}<0.0005)$ was taken as level of significance.

\section{Results:}

Total 100 subjects of both sexes were grouped as Group-I (50 control) and Group-II (50 case).

Table-I shows age and sex distribution of the study population and table II shows the comparison of HS CRP between Group-I and Group-II

Table I

Grouping of study subjects \& age and sex distribution

\begin{tabular}{lcccc}
\hline Groups & Status & Mean age(years) & Male & Female \\
G-I $(n=50)$ & Control & 26 & 37 & 13 \\
G-II $(n=50)$ & CRF & 31 & 38 & 12 \\
\hline
\end{tabular}

Table-II

Comparison of HS CRP between Group-I (control) \& CRF (Group-II)

\begin{tabular}{lccc}
\hline Parameter & $\begin{array}{c}\text { Group-I (Control) } \\
\mathrm{n}=50 \mathrm{Mean} \pm \mathrm{SD}\end{array}$ & $\begin{array}{c}\text { Group-II (Case) } \\
\mathrm{n}=50 \mathrm{Mean} \pm \mathrm{SD}\end{array}$ & $\begin{array}{c}\text { Level of significance } \\
\text { ('p' value) }\end{array}$ \\
\hline HS CRP $(\mathrm{mg} / \mathrm{l})$ & $25.5 \pm 0.29$ & $75.5 \pm 38.88$ & $<0.0005^{*}$ \\
\hline
\end{tabular}

Mann- Whitney U test done (2- tailed)

* Highly significant

Table-III shows the correlation between creatinine and creatinine clearance which is highly significant and Figure-1 shows the curvilinear relationship between creatinine and creatinine clearance. 
Table-III

Correlation between Creatinine and Creatinine clearance

\begin{tabular}{cccc}
\hline $\begin{array}{c}\text { Creatinine } \\
(\mathrm{mg} / \mathrm{dl})\end{array}$ & $\begin{array}{c}\text { CCR }(\mathrm{ml} / \mathrm{min}) \\
\mathrm{n}=50\end{array}$ & 'r' value & 'p'value \\
$\mathrm{n}=50$ & Mean $\pm \mathrm{SD}$ & & \\
Mean $\pm \mathrm{SD}$ & & & \\
\hline $2.711 \pm 1.068$ & $39.93 \pm 17.82$ & -0.882 & $<0.0005^{*}$ \\
\hline
\end{tabular}

Highly significant

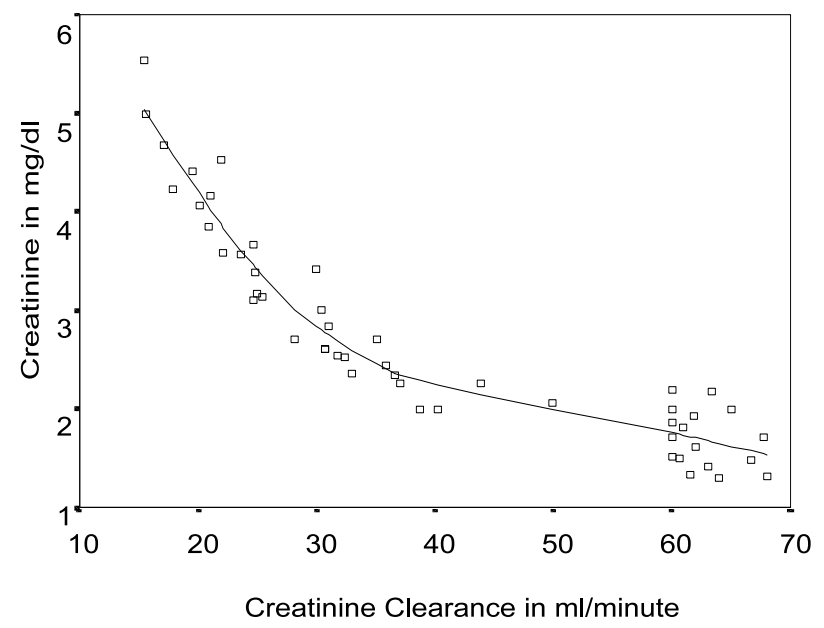

Fig.-1: Scattered diagram of serum creatinine versus creatinine clearance

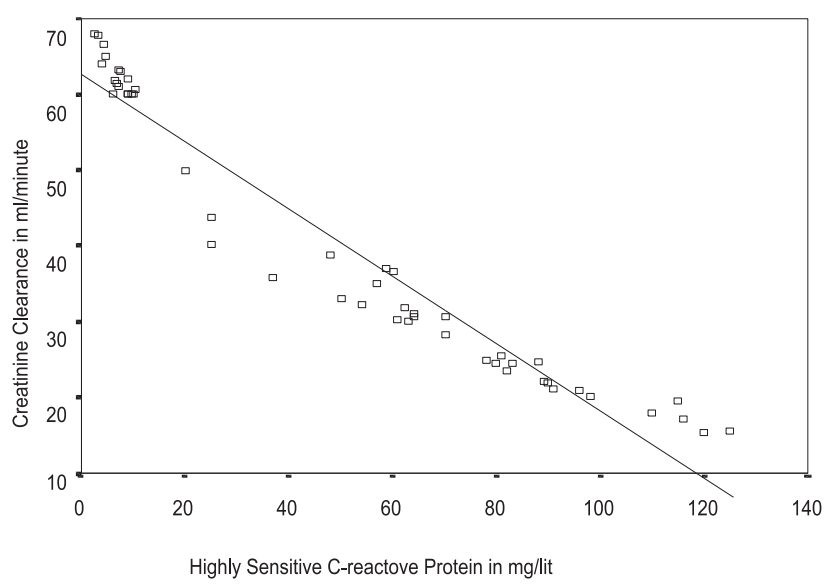

Fig.-3: shows the regression line of creatinine clearance on HS CRP.

The fitted regression line is Expected mean CCR $=62.6-.444 \times$ HS CRP. From table $-\mathrm{V}$ the
Table IV and figure-2 show the high negative significant correlation between HS CRP and creatinine clearance.

Table-IV

Correlation between HS CRP and CCR

\begin{tabular}{cccc}
\hline $\begin{array}{c}\text { HS CRP }(\mathrm{mg} / \mathrm{l}) \\
\mathrm{n}=50\end{array}$ & $\begin{array}{c}\text { CCR }(\mathrm{ml} / \mathrm{min}) \\
\mathrm{n}=50\end{array}$ \\
$\mathrm{Mean} \pm \mathrm{SD}$ & Mean $\pm \mathrm{SD}$ & & \\
\hline $50.938 \pm 38.880$ & $39.993 \pm 17.828$ & -0.968 & $<0.0005^{*}$ \\
\hline
\end{tabular}

* Highly significant

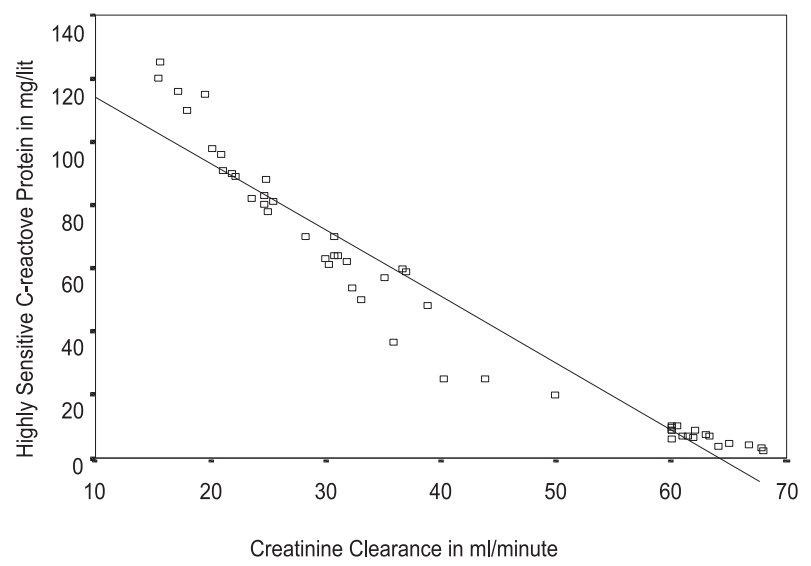

Fig.-2: Scatter diagram of creatinine clearance versus HS CRF

estimated regression line is $\mathrm{Y}=62.60-0.44 \mathrm{x}$, $\mathrm{Y}=\mathrm{CCR}, \mathrm{X}=\mathrm{HS} \mathrm{CRP}$. Both the coefficients are found to be significant. A co-efficient of CCR,0.44 means that if HS CRP is increase by one unit $(\mathrm{mg} / \mathrm{l})$ then on an average creatinine clearance will decrease by an amount of . $44 \mathrm{ml} /$ min. The high value of $R^{2}=0.937 \mathrm{implies}$ a good fit of the model that is $93.7 \%$ of the total variation in the values of creatinine clearance can be explain by the fitted model.

Figure-3: Sample regression line of CCR on HS CRP shows creatinine clearance in healthy control subjects (Group-I) and chronic renal failure patients as cases (Group-II) to evaluate the involvement of HS CRP in CRF. The present study has revealed the mean serum HS CRP concentration $1.12 \pm 0.29 \mathrm{mg} / \mathrm{l}$ in healthy control group. This is consistent with several other studies ${ }^{8}$. 
Table-V

Model summery of regression analysis

\begin{tabular}{cccccc}
\hline Model Variables & $\begin{array}{c}\text { Estimates of } \\
\text { co-efficient }\end{array}$ & & 't'value 'p'value & $\mathrm{R}^{2}$ \\
\hline 1 & Intercept & 62.601 & 58.952 & $<0.0005$ & 0.937 \\
& HS CRP & -0.444 & -26.685 & $<0.005$ & \\
\hline
\end{tabular}

\section{Discussion:}

In this case control study we have measured the serum HS CRP, serum urea, serum creatinine and creatinnne clearance. Mean serum HS CRP concentration found in Group-II (CRF) was $50.938 \pm 38.88 \mathrm{mg} / \mathrm{l}$ and ranges from $2.4-125 \mathrm{mg} / \mathrm{l}$. Chronic renal failure (Group-II) patients of this study has shown serum HS CRP concentration significantly higher in comparison to control (Group-I) ${ }^{8,9}$. In Group-IIA, Group-IIB and Group-II C mean serum HS CRP concentration has been found that 6.83 $\pm 2.49,51.18 \pm 15.87$ and $94.82 \pm 16.54 \mathrm{mg} / 1$ respectively. That is serum HS CRP concentration increases according to severity of renal failure. Same phenomenon observed in many other studies around the world ${ }^{10}$.

The present study searched for a correlation between HS CRP and creatinine clearance and found a negative correlation between HS CRP and creatinine clearance and a positive correlation co-efficient in between HS CRP and creatinine and urea where $\mathrm{r}=$ .937 and .783 respectively. In the present study a comparison has been done between creatinine clearance and serum creatinine. Figure- 1 shows that serum creatinine does not increase at a significantly higher level until the serum creatinine clearance has been grossly reduced. So it can be suggested that in early failure serum creatinine is not sufficient to indicate the renal function loss. Whereas Figure2 of this study shows a comparison between CCR and HS CRP. Where decreased renal function loss from the very beginning is reflected by increase in HS CRP. This observation suggests that in early renal failure HS CRP along with CCR can be good markers of CRF than creatinine clearance alone. This findings is in consistent with other studies ${ }^{11}$.

The statistical analysis of the present study shows that serum HS CRP is significantly higher than control and the increased concentration is directly proportional to the severity of renal function loss where serum urea, creatinine and creatinine clearance are markers of the severity. This study also shows that in early CRF HS CRP is a better marker of renal function loss than creatinine clearance alone. This finding is in consistent with other's findings ${ }^{12}$.

From this study, we can suggest that HS CRP should be done with the other parameters in CRF patients for early diagnosis in the irreversible stage so that further progression of the disease can be arrested.

Above findings tend to support that HS CRP is a good stable marker predictor of Chronic renal failure despite the fact that it is an acute phase reactant. It also supports the measurements of serum HS CRP along with serum urea, creatinine and creatinine clearance to predict future chronic renal failure in a more dependable and authentic manner.

\section{References:}

1. Mendall MA, Patel P, Ballan L et al ; cited by Stuveling EM, Hielege HL, Bakar JL, Reinold OB, DD. C-Reactive Protein is Assotiated With Renal Function Abnormalities in a Non- Zeeuw Diabetic Population. Kidney international. 2003; 63: 654-61.

2. Haslett C, Chilvers ER, Hunter A, Boon NA. eds. In: Davidson's Principle and Practice of Medicine, 1999; $18^{\text {th }}$ edi. UK. 1999: 433-39.

3. Barrett Bj, Bolton WK, Barry JM et al. Clinical Practice Guidelines for the Management of Anaemia Co-existant with Chronic Renal Failure. J American Soc Nephrol 1999; 10: 873-76.

4. Barrett Bj, Bolton WK, Barry JM et al. Clinical Practice Guidelines for the Management of Anaemia Co-existant with Chronic Renal Failure; J American SocNephrol 1999; 10: 873-76.

5. Vigushin DM, Peps MB, Hawkins PN. Metabolic and Scintigraphic Studies of Radio-Iodinated Human C-Reactive Protein in Health and Disease; J Clin Invest 1993; 91: 1351-57.

6. Panichi V, Migliori M, Pietro M, Taccola D, Bianchi MA, Norpoth AM, Metelli M, Giovannini MR, Tetta C, Palla R. C-Reactive Protein in Patients With Chronic Renal Diseases. Renal Failure: 2001; 23: 551-562.

7. Dewnter RJ, Fischer J, Bholaa Sing R, Van Straalen JP, JJong TD, Tijssen Jen GP, Sanders GT; C- 
JM Vol. 7, No. 1

Reactive Protein and Cardiac Troponin T in Risk Stratification: Differences in Optimal Timming of Tests Early After the Onset of Chest Pain; Clinical Chemistry. 2000; 46: 1597-1603.

8. Lab Test Online ; HS CRP ; The Test Sample ; American Association for Clinical Chemistry; Availablefrom:<http://www.labtestonline.org/ understanding/analytes/HS CRP/glance; 30.05.2004.

9. Yeh ETH, Willerson JT . Coming of Age of C-Reactive Protein. Circulation: 2003; 107(3): 370-72.

10. Stuveling EM, Hielege HL, Bakar JL, Paul E,
Zeeuw DD; C-Reactive Protein is Assotiated With Renal Function Abnormalities in a Non -Diabetic Population. Kidney international: 2003; 63; 654661.

11. Nelson RG, Bennett P, Beck GJ, Mington M, Mitch WE, Myers BD. Dovelopment And Progression of Renal Disease In PIMA Indians With Non Insulin Dependent Diabetes Mellitus; The New Eng. J Med 1996; 28: 1636-44.

12. Nakahara C, Kanemoto C, Saito K, Oyake N, Kamoda Y, Nagata T, Matsui M. C-Reactive Protein Frequently Localizes in the Kidney in Glomerular Diseases. Clinical Nephrol; 2001; 55: 365-70. 